IFAS Extension

\title{
Converting the Beef Cow Herd to a Controlled Breeding Season ${ }^{1}$
}

Tim Wilson, Cindy Sanders, Mark Warren, Matt Hersom, and Curt Lacy ${ }^{2}$

\section{Introduction}

Controlled breeding in beef cattle production is defined as developing specific predetermined strategies on when to begin and end a breeding season. The length of a controlled breeding season varies depending on factors such as the marketing objective, size of the operation, and personal preference. Some controlled breeding seasons last only a few weeks whereas others last several months. Although controlled breeding seasons have been recommended for a long time, approximately $45 \%$ of cow-calf operators in the Southeast United States continue to breed using a year-round breeding season (USDA 2010). Implementing a controlled breeding season to manage the length of the calving season is a cost-effective management practice that beef cattle producers can adopt (Troxel 2011).

The advantages of establishing a controlled breeding season include the following (adapted from Triplett SR1005):

- Nutrition can be adjusted according to physiological status

- Cows can be closely observed for calving difficulty

- Calf crop will be more uniform in weight and age for marketing

- Application of management and labor can be concentrated

- Identification of reproductively unsound cows is facilitated

\section{How to Convert to a Controlled Breeding Season}

Beef cattle producers who use year-round breeding and would like to convert to a 90-day controlled breeding season can do so in a three- to four-year program. This conversion will involve choosing a final day for breeding. Cattle not pregnant after this date will be culled. Once a date has been determined, managers should assess production records and determine if a large number of cows will be culled. If so, it may be necessary to re-evaluate the breeding dates. Producers may consider split calving seasons if these breeding dates are desired.

Using split calving seasons involves dividing one herd into two, which results in two breeding seasons and two calving seasons. It also reduces the number of bulls needed during breeding because the cow herd is split into two groups. To successfully incorporate a split calving season method of controlled breeding requires additional pastures, management, and time. Producers limited in these resource areas should consider an alternative approach.

\section{Preparations}

To successfully complete the transition from year-round breeding to a controlled breeding season, a strong bull pen must be constructed to hold bulls when they are removed

1. This document is AN267, one of a series of the Animal Sciences Department, Florida Cooperative Extension Service, Institute of Food and Agricultural Sciences, University of Florida. Original publication date August 2011. Visit the EDIS website at http://edis.ifas.ufl.edu.

2. Tim Wilson, extension agent II, Bradford County Extension, Starke, FL; Cindy Sanders, extension agent II, Alachua County Extension, Gainesville, FL; Mark Warren, extension agent I, Flagler County Extension, Bunnell, FL; Matt Hersom, associate professor, Department of Animal Sciences; and Curt Lacy, associate professor, Agriculture and Applied Economics Department, University of Georgia, Tifton, GA; Florida Cooperative Extension Service, Institute of Food and Agricultural Sciences, University of Florida, Gainesville, FL 32611. 
from the herd. Bulls can escape from inadequate facilities and reenter the cow herd. If producers do not want to build additional pens or have limited acreage, there are other alternatives to separate bulls from the herd. These alternatives include maintaining bulls at a remote pasture, leasing pasture space specifically for bulls, or leasing bulls. Bulls should undergo a complete breeding soundness exam prior to the initiation of the breeding period to ensure healthy, fertile, and functional bulls are used.

Producers must determine a timeline of events that begins with their intended market end-point, or date of sale for calves. Identifying a market end-point is the first step in determining when calves should be weaned. The determined market end-point will provide the direction needed to produce the type of calf acceptable to subsequent segments of the beef industry (i.e., age, type, weight, etc.).

Knowing where calves will be sold can help determine what management practices should be performed and when they should be completed. Multiple factors, such as forage availability, temperature, market trends, and labor, should be considered when determining the market end-point.

A simple-to-follow timeline presented in Table 1 or Figure 1 can be used to convert from a year-round breeding program using a three- to four-year approach. Using this method of conversion, cows are gradually culled over multiple years, thereby decreasing the number of cows culled in a single year. Another resource that demonstrates these same steps using a spreadsheet can be found at www. secattleadvisor.com.

\section{First Year}

To begin converting from a year-round breeding season to a defined, controlled breeding season, the last day of the breeding season must be determined. On this day, remove bulls from the cow herd and exclude them for six months. This last day will be the last day for future controlled breeding seasons, and bulls will be subsequently removed every year on this day. Sixty days after the end of the breeding season all cattle should be evaluated for pregnancy. Age of pregnancy can be determined, and this will facilitate grouping the cows according to expected calving date. Open females without a calf or with a calf that is five months old or older should be culled from the breeding herd and marketed accordingly (Triplett SR1005).

After a six-month exclusion period, bulls reenter the cow herd and are allowed to breed cows for six months. At the completion of this breeding season, all cows should be evaluated for pregnancy and culled as described above.

\section{Second Year}

Bulls are excluded from the herd for $71 / 2$ months and then are reintroduced to the cow herd and allowed to breed for $4 \frac{1}{2}$ months. All cows determined open during the 60 -day post-breeding season pregnancy evaluation should be culled.

\section{Third Year}

After the completion of the $4 \frac{1}{2} 2$-month breeding season, bulls will remain excluded from the cow herd for nine months. This procedure will begin the 90 -day breeding season and complete the goal of a controlled breeding season. After the breeding season is completed, all open cows should be culled. The defined breeding season should begin and end each year with these same breeding dates adjusted for leap years.

\section{Summary}

Controlled breeding offers cow-calf producers many benefits related to management and profits. Facilitating herd health activities, culling reproductively unsound cattle, and marketing a uniformed calf crop all have positive impacts on production revenue. If you have questions related to controlled breeding or how to successfully complete this process, contact your county Extension agent, state beef Extension specialist, or large animal veterinarian.

\section{Literature Cited}

Triplett, C.M. A Controlled, Seasonal Cattle Breeding Program. Southern Regional Beef Cow-Calf Handbook SR1005.

Troxel, T.R. 2011. "Real-life Implementation of Controlled Breeding Season." In 2011 Florida Beef Cattle Short Course, 47-52. Gainesville: University of Florida, Institute of Food and Agricultural Sciences.

USDA. 2010. Beef 2007-08, Part V: Reference of Beef CowCalf Management Practices in the United States, 2007-08. USDA-APHIS-VS. 
Table 1. Suggested steps for converting to a 90-day controlled breeding season ${ }^{1}$

\begin{tabular}{|c|c|}
\hline \multirow[b]{2}{*}{ Year 1} & Action \\
\hline & \\
\hline 1. & Build a good, strong bull pen. \\
\hline 2. & Remove bulls from herd. \\
\hline \multirow[t]{2}{*}{3.} & Check pregnancy of all cows. \\
\hline & $\begin{array}{l}\text { Cull: } \\
\text { All open breeding-age heifers. } \\
\text { All open cows with calves five months of age or older. }\end{array}$ \\
\hline 4. & Place bulls with cows for 6 months. \\
\hline 5. & Breed replacement heifers 3-4 weeks ahead of the final long-range planned breeding. \\
\hline \multicolumn{2}{|l|}{ Year 2} \\
\hline 1. & Follow all previous steps except leave bulls with cows for $4 \frac{1}{2} 2$ months. \\
\hline \multicolumn{2}{|l|}{ Year 3} \\
\hline 1. & Follow all previous steps except leave bulls with cows for 80-90 days. \\
\hline 2. & Cull all open cows regardless of age of their calves. \\
\hline 3. & The breeding season may be reduced even further in following years. \\
\hline
\end{tabular}

Figure 1a. through 1f. Timeline for converting a beef cow herd from a year-round breeding season to a controlled breeding season

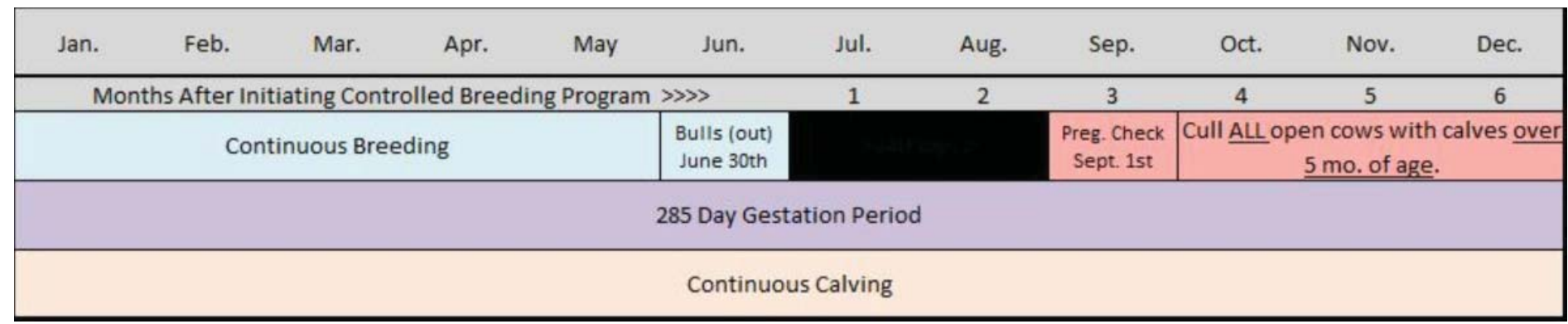

Figure 1a. Current Year, Year 1 (Continuous Calving)

\begin{tabular}{|c|c|c|c|c|c|c|c|c|c|c|c|}
\hline Jan. & Feb. & Mar. & Apr. & May & Jun. & Jul. & Aug. & Sep. & Oct. & Nov. & Dec. \\
\hline 7 & 8 & 9 & 10 & 11 & 12 & 13 & 14 & 15 & 16 & 17 & 18 \\
\hline \multicolumn{5}{|c|}{ Bulls with Cows beginning Jan. 1st } & $\begin{array}{l}\text { Bulls (out) } \\
\text { June 30th }\end{array}$ & & & $\begin{array}{l}\text { Preg. Check } \\
\text { Sept. 1st }\end{array}$ & \multicolumn{3}{|c|}{ Cull ALL open cows. } \\
\hline \multicolumn{4}{|c|}{ Gestation Ends April 11th } & \multicolumn{8}{|c|}{285 Day Gestation Period (Gestation Starts Jan. 1st) } \\
\hline \multicolumn{4}{|c|}{ Calving Ends April 11th } & \multicolumn{4}{|c|}{ Proposed Weaning } & & \multicolumn{3}{|c|}{$\begin{array}{l}180 \text { Day Calving Season: } \\
\text { Starts Oct. 12th }\end{array}$} \\
\hline
\end{tabular}

Figure 1b. Year 2 (continuous to 180-day Calving) 


\begin{tabular}{|c|c|c|c|c|c|c|c|c|c|c|c|}
\hline Jan. & Feb. & Mar. & Apr. & May & Jun. & Jul. & Aug. & Sep. & Oct. & Nov. & Dec. \\
\hline \multirow[t]{3}{*}{19} & 20 & 21 & 22 & 23 & 24 & 25 & 26 & 27 & 28 & 29 & 30 \\
\hline & \multicolumn{4}{|c|}{ Bulls with Cows beginning Feb. 12th } & $\begin{array}{l}\text { Bulls (out) } \\
\text { June 30th }\end{array}$ & & & $\begin{array}{l}\text { Preg. Check } \\
\text { Sept. 1st }\end{array}$ & \multicolumn{3}{|c|}{ Cull ALL open cows. } \\
\hline & \multicolumn{3}{|c|}{ Gestation Ends April 11th } & \multicolumn{8}{|c|}{ 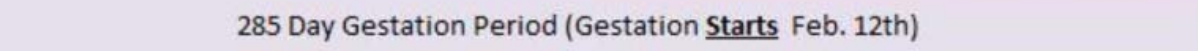 } \\
\hline \multicolumn{4}{|c|}{ Calving Ends April 11th } & \multicolumn{4}{|c|}{ Proposed Weaning } & & & \multicolumn{2}{|c|}{$\begin{array}{c}138 \text { Day Calving Season } \\
\text { Starts Nov. 24th }\end{array}$} \\
\hline
\end{tabular}

Figure 1c. Year 3 (180- to 138-day Calving)

\begin{tabular}{|c|c|c|c|c|c|c|c|c|c|c|c|}
\hline Jan. & Feb. & Mar. & Apr. & May & Jun. & Jul. & Aug. & Sep. & Oct. & Nov. & Dec. \\
\hline 31 & 32 & 33 & 34 & 35 & 36 & 37 & 38 & 39 & 40 & 41 & 42 \\
\hline & & & $\begin{array}{r}\text { Bulls } \\
\text { beginn }\end{array}$ & $\begin{array}{l}\text { Cows } \\
\text { pril 1st }\end{array}$ & $\begin{array}{l}\text { Bulls (out) } \\
\text { June } 30 \text { th }\end{array}$ & & & $\begin{array}{c}\text { Preg. Check } \\
\text { Sept. 1st }\end{array}$ & \multicolumn{3}{|c|}{ Cull ALL open cows. } \\
\hline Ges & Ends & 11th & & \multicolumn{8}{|c|}{ 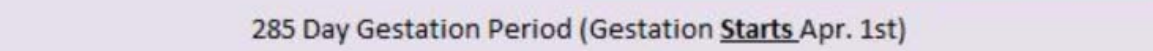 } \\
\hline \multicolumn{4}{|c|}{ Calving Ends - April 11th } & \multicolumn{4}{|c|}{ Proposed Weaning } & & & & \\
\hline
\end{tabular}

Figure 1d. Year 4 (138- to 90-day Calving)

\begin{tabular}{|c|c|c|c|c|c|c|c|c|c|c|c|}
\hline Jan. & Feb. & Mar. & Apr. & May & Jun. & Jul. & Aug. & Sep. & Oct. & Nov. & Dec. \\
\hline 43 & 44 & 45 & 46 & 47 & 48 & 49 & 50 & 51 & 52 & 53 & 54 \\
\hline & & & $\begin{array}{l}\text { Bulls } \\
\text { beginr }\end{array}$ & $\begin{array}{l}\text { Cows } \\
\text { oril 1st }\end{array}$ & $\begin{array}{l}\text { Bulls (out) } \\
\text { June 15th }\end{array}$ & & $\begin{array}{l}\text { Preg. Check } \\
\text { Aug. 15th }\end{array}$ & \multicolumn{4}{|c|}{ Cull ALL open cows. } \\
\hline $\mathrm{Ge}$ & Ends & 1 th & & \multicolumn{4}{|c|}{285 Day Gestation Period } & \multicolumn{3}{|c|}{ Gestation $\underline{\text { Starts Apr. 1st }}$} & \\
\hline \multicolumn{4}{|c|}{$\begin{array}{l}90 \text { Day Calving Season } \\
\text { Jan. } 10 \text { th- Apr. } 11 \text { th }\end{array}$} & & & \multicolumn{2}{|c|}{ Proposed Weaning } & & & & \\
\hline
\end{tabular}

Figure 1e. Year 5 (90- to 80-day Calving)

\begin{tabular}{|c|c|c|c|c|c|c|c|c|c|c|c|}
\hline Jan. & Feb. & Mar. & Apr. & May & Jun. & Jul. & Aug. & Sep. & Oct. & Nov. & Dec. \\
\hline 55 & 56 & 57 & 58 & 59 & 60 & 61 & 62 & 63 & 64 & 65 & 66 \\
\hline & & & $\begin{array}{l}\text { Bulls } \\
\text { beginr }\end{array}$ & $\begin{array}{l}\text { Cows } \\
\text { pril 1st }\end{array}$ & $\begin{array}{l}\text { Bulls (out) } \\
\text { June 15th }\end{array}$ & & $\begin{array}{l}\text { Preg. Check } \\
\text { Aug. 15th }\end{array}$ & \multicolumn{4}{|c|}{ Cull ALLopen cows. } \\
\hline \multicolumn{3}{|c|}{ Gestation Ends Mar. 27th } & \multicolumn{9}{|c|}{ Gestation $\underline{\text { Starts Apr. 1st }}$} \\
\hline \multicolumn{3}{|c|}{$\begin{array}{l}80 \text { Day Calving Season } \\
\text { Jan. } 10 \text { th-Mar. } 27 \text { th }\end{array}$} & & & & & \multicolumn{2}{|l|}{ Weaning } & & & \\
\hline
\end{tabular}

Figure 1f. Year 6 and Beyond 